\title{
Self-Disclosure through Self-Compassion: A Window on the Mind of Teachers
}

\section{Merissa B. Ocampo \\ Fukushima Gakuin College}

\section{Reference Data}

Ocampo, M. B. (2021). Self-disclosure through self-compassion: A window on the mind of teachers. In P. Clements, R. Derrah, \& P. Ferguson (Eds.), Communities of teachers \& learners. JALT. https://doi.org/10.37546/JALTPCP2020-06

This paper draws upon four intimate case studies of non-Japanese full-time English teachers based in Tokyo, identifying ongoing workplace stressors and lifestyle adjustments that impact teachers' professional performance and private life satisfaction. The study employed narrative group work, eight-week meditation, and solicited diaries to examine self-compassion, self-care techniques and self-compassion fatigue, and overall psychological and emotional well-being of the participants. Specific sources of participants' exhaustion are identified, including pressures brought about by limited sources of teaching materials, the language barrier, and the need to teach in at least four different schools in a day. At the same time, it was revealed that emotional connection with colleagues, frequent communication with family, and meditation helped them to accept these problems positively. The benefits and associated challenges of using selfcompassion techniques and mindfulness with education professionals are also discussed in the paper. 本研究は, 東京に拠点を置く外国人英語講師を対象とした四つの事例研究を提示する中で講師の職業上の専門性と私生
活の满足度に影響を与える要因(職場のストレスやライフスイルル变更)の特をはかった。本研究では、ナラテイブ・゙ル

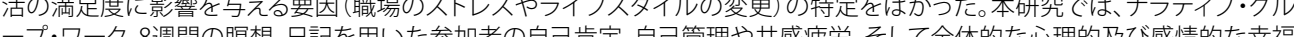

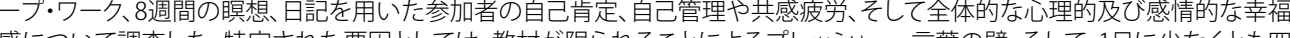
感について調查した。特定された要因としては、教材が限られることによるプレッシャ一、言葉の壁、そして、1日に少なくとも四 つの学校で講義せざるを得ない実態があげられる。同時に、同僚との心の結びつきや、家族との頻繁なコミユニケーション、 び瞑想が、これらの問題を解決する助けになったことが明らかになった。本研究は、教育の専門家に自己肯定やマインドフル ネスの方法を用いる利点と課題についても議論する。 elf-disclosure, or the sharing of emotions and feelings, both positive and negative, can help to improve any kind of relationship by promoting deeper understanding. Self-disclosure as a topic has received attention since the 1970s. As early as 1971, Jourard defined disclosure as "the act of making yourself manifest, showing yourself so that others can perceive you" (p. 19), which leads to the conclusion that "telling others about yourself through love and trust (positive disclosure) is paramount for relationships" (p. 19).

Opening up about one's feelings can be a great pathway towards understanding and managing the problems, misunderstandings or concerns that arise between people. However, such sharing can also make us aware that full disclosure may not always lead to the best outcomes. Self-disclosure may not always be the best way to manage one's emotions, and we should appreciate the risks and benefits associated with such emotional disclosure (Heath et al. 2017), which can even be a barrier to fully understanding an individual's feelings and thoughts. Nevertheless, the general efficacy of the promotion of self-disclosure of experiences through the cultivation of self-compassion has been proposed (Dupasquier et al. 2020; Neff \& Sands, 2015), and in this study $\mathrm{l}$ apply them to teachers. The present study probes whether fostering self-compassion promotes self-disclosure of anxiety, burnout, and stress (ABS), within teachers' working environments, and whether it indirectly lessens or intensifies any concerns they may have about being more compassionate to others and to themselves.

\section{Background}

One of the most fundamental characteristics of human beings is their social nature. Humans have a strong motivation to form social bonds and to share their experiences (Baumeister \& Leary, 1995). Sharing emotional experiences can even influence individual feelings, negatively and positively, depending on the context. Hess et al. (1995) noted that sharing effects can depend on the relationship with one's interlocutors, as well as on the type of situation that is shared and reasons for sharing these emotions. These reasons 
might be to release what is within their minds and hearts, whether it be good or bad, to relieve anxieties, and to improve communication. Keeping things bottled up or unshared can be unhealthy and can even lead to burnout and depression. However, to see things from different perspectives helps us organize our thoughts, sort things out, and attain some psychological relief. Human as we are, we are longing for closeness with other people and sharing helps foster this closeness. Such sharing of feelings is a powerful way to unload and thus lighten one's emotional burdens. On the other hand, unshared negative thoughts and feelings could become "anchors" that cause us to drown in our stress and anxiety. Fortunately, the avenue of sharing emotions can lead to the discovery of trusted people, which is an absolutely healthy step that may help effect an important change in someone's life. In Asian philosophy, these ideas have a long provenance within the three jewels of Taoism-compassion, moderation, and humility (Jones \& Rainville, 2014).

Self-compassion has been defined as being kind to oneself, even in moments of disappointment or distress (Neff \& Sands, 2015). It involves responding to presentmoment thoughts and feelings in a non-judgmental way, recognizing how people are connected by universal experiences of failure and suffering, and treating oneself with caring and warmth in times of distress. Furthermore, self-compassion is thought to promote engagement with one's suffering and to decrease avoidant coping that might thwart disclosure (Gilbert et al. 2017).

Individuals who receive a form of intimate disclosure feel an urge to respond with a similar level of disclosure in return (Kleinke, 1979). At the same time, self-disclosure can be a slightly delicate issue to approach because it involves the candid process of letting another person know what you think, feel, or want. Emotions may be contagious (Desautels, 2014), sudden, fleeting, and dependent on a variety of contextual factors (Heid, 2019). Frequently, through sharing feelings an individual in a highly emotional state can impact the emotions of others (Wild et al. 2001). Moreover, varied degrees of self-disclosure - both verbal and nonverbal, can be recognized. Humans disclose depending on the breadth of information given or the range of information shared, and the depth of information given can shift from relatively non-revealing messages to more personal ones. This is illustrated by the "onion metaphor" (Miles et al. 2015) and the social penetration theory (SPT) (Carpenter \& Greene, 2015), which suggests that selfdisclosure is the process of tearing layers of concentric circles away. The multi-layered onion is made up of a public self on the outer layer and private self at the core. As time passes and intimacy grows, the layers of one's personality begin to unfold to reveal the core of the person (peeling the onion levels), superficial, intimate, personal, and core. The notion of the onion metaphor was inspiring and encouraged me to apply it to my research, "going deeper" through disclosure to gain insight on teachers' minds through the lens of self-compassion.

\section{Participants}

\section{Research Methodology}

In this study, four teachers' case studies are drawn upon. These four participants, all of whom are non-Japanese English teachers based in Tokyo, are referred to in the text and tables of this paper by the pseudonyms Katherine, Sally, Jo, and Penelope. Several years ago, Penelope, who was known to the researcher socially, experienced mild burnout due to the impact of "frequent red-ink corrections" on her Japanese-as-a-second-language written workplace reports. She experienced difficulty in her working environment because of her limitations in Japanese proficiency, and as a result became negative about the working environment and experienced anxiety-related symptoms. Theoretically, she was sufficiently knowledgeable about the matter, but in practice had a hard time "finding balance and sorting things out with herself" (Participant Penelope, personal communication prior to the study, January 10,2019$)$.

Penelope shared that she had continued searching how to alleviate ABS by reading books and blogs and by watching YouTube video clips. While it took some time until she found mindful self-compassion, Penelope reported that she practiced the guided techniques, which are explained more in a later section, and realized their effectiveness. Hoping to assist in sharing this knowledge with other teachers of English in Japan, Penelope introduced the researcher to Katherine, who has been in Tokyo for more than 15 years as a full-time assistant English teacher (ALT) in junior high school, who in turn introduced the remaining participants (Sally and Jo).

Prior to beginning the sessions, participants were requested to sign a consent participation agreement. Throughout the study, I undertook the roles of the participants' "elder sister" and researcher at the same time. In this participant-observer role, I strove to exhibit kindness and generosity to all participants, making every effort to show them respect by using polite language, despite being much older than them, and by making sure to cultivate "a family like" environment (Ocampo, 2015). During the eight-week self-compassion meditation, participants were also given a minimal transportation monetary support.

\section{Data Collection}

Data collection took place during and directly after an eight-week series of selfcompassion meditation workshop (SCMW) sessions conducted in Tokyo from September 
2019 to January 2020. Four of these sessions were held in participants' apartments, three in restaurants in the Tokyo area, and the final session at an onsen [hot spring bath]. At the beginning of the series of SCMW sessions, participants were provided with a selfcompassion booklet and self-compassion guide, which they were asked to take home and read at their own pace. The contents of the self-compassion booklet are: Practice 1: The self-compassion body scan, Practice 2: Self-acceptance, Practice 3: Embracing suffering, Practice 4: Healing pain from the past, Practice 5: Going deeper, Practice 6: When compassion is difficult, Practice 7: Natural compassion, and Practice 8: Cultivating joy (Desmond, 2017).

At these SCMW sessions, the participants met together with the researcher for periods of at least 90 minutes, with each session focusing on one of the eight practices listed above. The sessions included (1) narrative group work and (2) guided meditation. The participants were also asked to do (3) individual diary work (Hyers, 2018) and self-led mindfulness activities outside the group sessions.

Narrative group work was conducted orally, but usually began with a group reading from the relevant section of the self-compassion guide, which acted as a springboard for discussion. The researcher used fieldwork notes as a written record of the eight sessions, two of which were also audio recorded. Meditation was guided by the researcher with the support of relaxation sounds and music that were freely available for public use on the Internet.

After completing the first five SCMW sessions, having become comfortable with the sessions and developing a positive degree of trust with the researcher, during session six, in which the focus was on Practice 6, the participants were also requested to answer the Fears of Compassion questionnaire. The questionnaire incorporates three scales measuring fear of compassion (Gilbert et al. 2011): Scale 1, fear of feeling or expressing compassion for others (10 items, e.g., Being too compassionate makes people soft and easy to take advantage of); Scale 2, fear of receiving compassion from others (13 items, e.g., I try to keep my distance from others even if I know they are kind); and Scale 3, fears of compassion for self (15 items, e.g., I worry that if I start to develop compassion for myself $I$ will become dependent on it). Respondents used a Likert scale to rate how much they agree with each statement $(0=$ don't agree at all, $1=$ don't agree, $2=$ slightly agree, $3=$ =agree, $4=$ =completely agree).

\section{Results and Discussion}

\section{Narrative Group Work}

Written narrative inquiry, an idea that includes the interdisciplinary study of the activities involved in generating and analyzing stories of life experiences (e.g., life histories, narrative interviews, journals, diaries, memoirs, autobiographies or biographies), was carried out with the aim of deepening the effectiveness of selfcompassion to promote self-disclosure. SCMW narrative group work with these teachers identified the presence of ongoing workplace stressors and lifestyle adjustments that impact both their professional performance and private life satisfaction. For the first two SCMW sessions, the four participants made partial disclosures to the researcher in a group setting about challenges in their workplaces. As the sessions went deeper, they began to share some of their related personal worries and problems. The disclosure of these feelings ranged from positive to negative, even to the point where certain participants shared their tears during the sessions.

One of the participants, Katherine revealed that the pressure of her job, such as a limited source of teaching materials, the language barrier, and having to teach in multiple schools in a day, made her psychologically and physically exhausted. Being connected with colleagues, frequent communication with family, and meditation helped her to embrace the situation positively.

Figure 1 shows the self-compassion booklet and various practices introduced during the SCMW sessions, including laughing, simple yoga, eating, and crying. Based on a cumulative evaluation of the eight sessions as a participant observer, these expressions of self-compassion appeared to deepen the connection between us and towards selfdisclosure at the sessions.

Figure 1

Self-compassion Meditation Workshop (SCMW) Sessions.

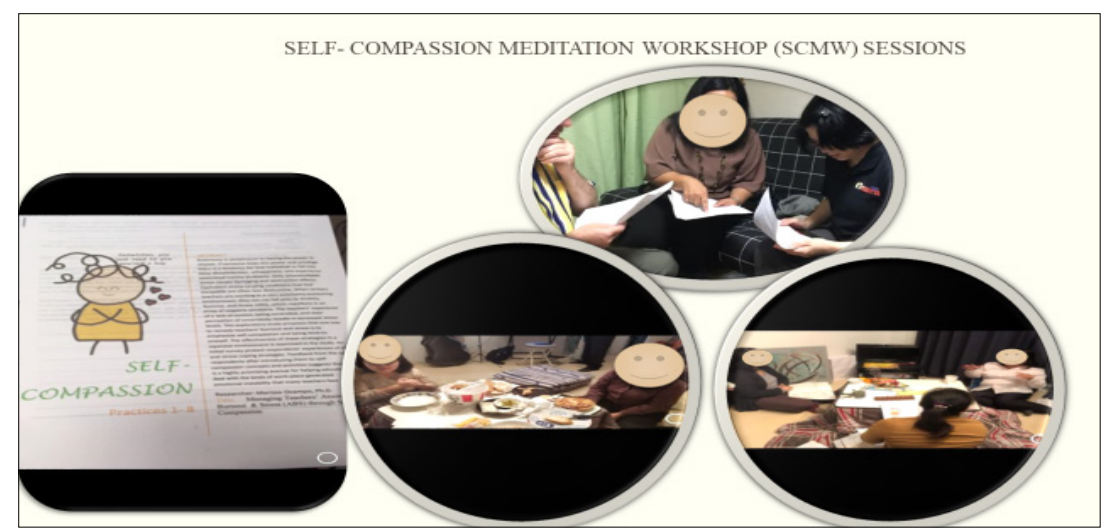




\section{Personal Feelings and Emotions During Difficult Times}

Katherine shared her insight and candid disclosure of personal feelings and emotions during a difficult time during COVID-19. Her biggest stresses during the pandemic outbreak were financial and related to the lockdown duration. Though she was a fulltime ALT, she was worried that her company might lessen her salary due to reduced face-to-face classes. She was also worried about her health. If she got sick, nobody would take care of her because she lives alone. Thankfully, a month later, her company paid her in full. Because of this, she kept herself busy doing online classes. She also watched and listened to Ted talks and YouTube videos about positivity, how to deal with stress and anxiety, and meditation. She received compassion and advice from her friends and family through online communication such as Facebook and Twitter. She admitted that she was not good at cooking. But because of the lockdown, she was able to learn different kinds of recipes that made her two-month stay at home worthwhile and interesting.

\section{Fear of Compassion Questionnaire}

In Practice 6, from the self-compassion booklet participants received at the beginning of the SCMW, which is "When compassion is difficult", respondents were asked whether they experienced any concerns or fear about compassion. Jo and Katherine shared the same fear that people would take advantage of them if they were forgiving and compassionate. They believed that people need to help themselves, rather than waiting for others to help them. Katherine and Penelope agreed, and Jo strongly agreed that for some people, discipline and proper punishment were actually more helpful (Appendix A).

When asked to respond to the expression of compassion from others (Appendix B), Penelope reported feeling anxious and embarrassed when people were kind and compassionate towards her. She revealed being fearful of becoming dependent on care from others because such care might not always be available, or willingly given, at times when she needed it most. Sally even said that when she received compassion from others she felt "sadness" because she felt that they pitied her. For her, such pity was extremely unwelcome, and she disliked it if others referred to her as kawai sou [poor girl]. When participants were asked about expressing kindness and compassion towards themselves (Appendix C), only Jo completely agreed that if they became kinder and less self-critical towards themselves their standards at work would drop. Jo also accepted that it was easier to be critical rather than compassionate towards herself. Moreover, Jo feared that being compassionate to herself would cause her to lose the ability to be self-critical, and result in her personal flaws being revealed. Based on her testimony, this was something she definitely did not want to happen. For her, showing her flaws was a sign of weakness. She wanted to portray herself as a strong and self-reliant person in a foreign country.

Individual Diary Work and Self-Led Mindfulness: Self-Disclosure through Narrative Diaries

Writing expressively about distressing experiences has been found to have beneficial health effects (Ashley et al. 2013) and studies suggest that written emotional disclosure can improve health and cognitive stress effects (Radcliffe et al. 2007). This was true for participant Katherine, who was prolific in her responses during the study. For this reason, her words are more strongly represented in this paper, allowing them to speak for themselves in the section directly below in which she shares her perceptions of workplace stress.

As an individual living in Japan, I always try to keep in mind that I am an "outsider" and that no matter what I do, they will never treat me as an equal. This minimizes my expectations towards situations and people in general to be in my favor. This is true for my job as an English teacher as well. As a result, I tend to hold back on my plans and ideas because of the Japanese teachers' comments and sentiments, to keep everything smooth sailing. Most of the time, I do not mind but there are just instances where I get frustrated and get annoyed at my situation. This sometimes result to me being "hostile" or being on "resistance" mode. I try to make my point across by raising my voice. But if I do not get my way I try to retreat and leave the Japanese teacher to his/ her task. I acknowledge that this situation is not a good feeling and contributes to my dismay and dissatisfaction towards my work. As a way to unburden myself, I do things that I feel I have control over. This compensates for the opposite feelings I have toward work. (Katherine, SCMW individual diary work shared with the researcher post SCMW in a personal communication, March 31,2020).

This candid disclosure of ABS in the context of sessions that set out to foster selfcompassion, tended to affirm the sessions' efficacy in providing a window on the minds of teachers. Such disclosure provides threads that can be taken up in the course of oral, narrative activity, which can then touch on issues such as participants' concerns about being more compassionate to others and towards themselves.

\section{Effectiveness of Self-Led Mindfulness}

At the first SCMW session, Katherine shared some of her frustrations as a person and as a teacher in Japan. The self-compassion concepts introduced seemed familiar to her, 
and she felt that she was already exercising them in her own way. Katherine sought to maintain a boundary between her personal and professional lives, while striving to find joy and enrichment in both areas. Keeping these areas separate enabled her to take on different roles, such as leader or friend, freeing her from the limited bounds of her workrelated role as teacher.

Although, as a rule, Katherine aimed to be patient and understanding in her dealings with others, she revealed that there are times when she would prefer not to be so, since there was a possibility that others would take advantage of her good nature. The SCMW helped her realize that despite her efforts to keep personal and professional spheres separate, there are times when personal concerns and negative feelings began to enter the workspace, making such a neat compartmentalization difficult, and allowing private negativity to affect her reactions to workplace situations.

When we experience the feeling of compassion, the care circuit in our brain releases oxytocin and natural opiates (Desmond, 2015, Woodruff \& Stevens, 2018), with the potential to also reduce mental distress. And through this practice, Katherine learned that it helped her brain's care circuit to relieve stress, anxiety, and negative emotions, especially during the COVID-19 outbreak. Practice 3 , which is the practice of embracing suffering, was found to be effective after Katherine practiced self-acceptance. For example, she began accepting the situations she was facing at that time without trying to change them in any way. This kind of deep acceptance is the best foundation for generating compassion. She reported receiving compassionate messages from her family overseas via email and Facebook Messenger conversations, self-selected multimedia messages from religious figures via YouTube or podcasts, and people she knows generally in conversation. She was also proactive in engaging in self-care strategies, which was a way of being compassionate to herself (Appendix D).

\section{Conclusion and Recommendation}

Through these case studies of non-Japanese English teachers based in Tokyo, the presence of ongoing workplace stressors, ABS, and lifestyle adjustments that impact teachers' professional performance and private life satisfaction were identified. Through the SCMW, self-compassion's efficacy in promoting self-disclosure of ABS, and its ability to lessen concerns about being compassionate were demonstrated. This further strengthened the researcher's hypothesis that self-compassion, which entails being warm and understanding toward ourselves when we suffer, fail, or feel inadequate, rather than ignoring our pain or flagellating ourselves with self-criticism, offers real improvements to teachers' well-being.
In this study, the participants were able to engage in profound self-disclosure through storytelling, interviews, and narrative writing, peeling towards the core of their "personal onions". Based on their feedback and the researcher's participant observation, they also experienced increased self-compassion. As a result, these participants began to build a sense of joy, regulate their emotions, and found themselves led towards a deep personal transformation. The intimate sharing, which took place during the research, speaks strongly in favor of narrative work with small numbers of participants as an avenue for exploring human emotions. However, it can be remarked that even if one strives for objectivity when conducting research, it is difficult to deal dispassionately with phenomena that touch our lives so directly and deeply. During the time we spent together, these informant teachers truly became my teachers, and it is an honor to be able to share the insights I have gained from the process of close and intimate disclosure through self-compassion during this project. While the participants in this project were all non-Japanese teachers, residing in Tokyo, in future research $\mathrm{I}$ hope to expand this inquiry towards other groups of teachers in different contexts, aiming towards a more nuanced understanding of the efficacy of self-compassion to promote narrative disclosure and improve wellbeing.

\section{Bio Data}

Merissa B. Ocampo is a graduate of Hokkaido University and has been a full-time lecturer at Fukushima Gakuin College since 2017. Her research combines health and education, looking particularly at the impact of anxiety, burnout, and stress (ABS) on learners and teachers of English as a Foreign Language. Currently, she is developing a series of bilingual, illustrated mini books, which promote positive psychology. $<$ merissao@yahoo.com>

\section{References}

Ashley, L., O'Connor, D. B., \& Jones, F. (2013). A randomized trial of written emotional disclosure interventions in schoolteachers: Controlling for positive expectancies and effects on health and job satisfaction. Psychology, Health \& Medicine, 18(5), 588-600. https://doi.org/10.1080/13548506 .2012 .756536

Baumeister, R. F., \& Leary, M. R. (1995). The need to belong: Desire for interpersonal attachments as a fundamental human motivation. Psychological Bulletin, 117(3), 497. https://doi. org/10.1037/0033-2909.117.3.497 
Carpenter, A., \& Greene, K. (2015). Social penetration theory. The international encyclopedia of interpersonal communication, 1-4. https://doi.org/10.1002/9781118540190.wbeic160

Desautels, L. (2014). Emotions are contagious. Scholarship and professional work-education. College of Education, Butler University. Retrieved from https://digitalcommons.butler.edu/cgi/ viewcontent.cgi?article $=1098 \&$ context=coe_papers

Desmond, T. (2015). Self-compassion in psychotherapy: Mindfulness-based practices for healing and transformation. WW Norton \& Company.

Desmond, T. (2017). The self-compassion skills workbook: A 14-day plan to transform your relationship with yourself. WW Norton \& Company.

Dupasquier, J. R., Kelly, A. C., Moscovitch, D. A., \& Vidovic, V. (2020). Cultivating self-compassion promotes disclosure of experiences that threaten self-esteem. Cognitive Therapy and Research, 44(1), 108-119. https://doi.org/10.1007/s10608-019-10050-x

Gilbert, P., Catarino, F., Duarte, C., Matos, M., Kolts, R., Stubbs, J., \& Basran, J. (2017). The development of compassionate engagement and action scales for self and others. Journal of Compassionate Health Care, 4(1), 1-24. https://doi.org/10.1186/s40639-017-0033-3

Heath, P. J., Brenner, R. E., Vogel, D. L., Lannin, D. G., \& Strass, H. A. (2017). Masculinity and barriers to seeking counseling: The buffering role of self-compassion. Journal of counseling psychology, 64(1), 94.

Heid, M. (2019). Is sharing your feelings always healthy? Retrieved from https://elemental.medium. com/is-sharing-your-feelings-always-healthy-a6be3579c4ae, April, 2, 2021.

Hess, U., Banse, R., \& Kappas, A. (1995). The intensity of facial expression is determined by underlying affective state and social situation. Journal of personality and social psychology, 69(2), 280.

Hyers, L. L. (2018). Diary methods. Oxford University Press.

Jones, S., \& Rainville, K. N. (2014). Flowing toward understanding: Suffering, humility, and compassion in literacy coaching. Reading \& Writing Quarterly, 30(3), 270-287. Retrieved from https://doi.org/10.1080/10573569.2014.909270

Jourard, S. M. (1971). The transparent self. Van Nostrand Reinhold Company.

Kleinke, C. L. (1979). Effects of personal evaluations. In G. J. Chelune (Ed.), Self-disclosure: Origins, patterns, and implications of openness in interpersonal relationships (pp. 59-79). San Jossey-Bass.

Miles, M., Chapman, Y., \& Francis, K. (2015). Peeling the onion: Understanding others' lived experience. Contemporary Nurse, 50(2-3), 286-295. https://doi.org/10.1080/10376178.2015.1067 571

Neff, K., \& Sands, X. (2015). Self-compassion: The proven power of being kind to yourself (p. 320). NY: William Morrow.
Ocampo, M. (2015). Family environment mode approach (FEMA): An "anxiety buster" to motivate EFL learners. 21 $1^{\text {st }}$ Century Academic Forum: Third 21 ${ }^{\text {st }}$ CAF Conference Proceedings, 6(1), 260-272. Retrieved from https://www.21caf.org/uploads/1/3/5/2/13527682/25_ocampo.pdf

Radcliffe, A. M., Lumley, M. A., Kendall, J., Stevenson, J. K., \& Beltran, J. (2007). Written emotional disclosure: Testing whether social disclosure matters. Journal of social and clinical psychology, 26(3), 362-384. https://doi.org/10.1521/jscp.2007.26.3.362

Wild, B., Erb, M., \& Bartels, M. (2001). Are emotions contagious? Evoked emotions while viewing emotionally expressive faces: quality, quantity, time course and gender differences. Psychiatry Research, 102(2), 109-124. https://doi.org/10.1016/S0165-1781 (01)00225-6

Woodruff, C. C., \& Stevens, L. (2018). Where caring for self and others lives in the brain, and how it can be enhanced and diminished: Observations on the neuroscience of empathy, compassion, and self-compassion. In The Neuroscience of Empathy, Compassion, and Self-Compassion (pp. 285 320). Academic Press. https://doi.org/10.1016/B978-0-12-809837-0.00011-8

\section{Appendix A}

Fear of Compassion

Participants' Pseudonyms

\section{Fear of Compassion}

1. People will take advantage of me if they see me as too compassionate

2. Being compassionate towards people who have done bad things is letting them off the hook

3. There are some people in life who don't deserve compassion

4. I fear that too compassionate makes people an easy target

5. People will take advantage of you if you are to forgiving and compassionate

6. I worry that if I am compassionate, vulnerable people can be drawn to me and drain my emotional resources

\begin{tabular}{cccc}
\multicolumn{4}{c}{ Participants' Pseudonyms } \\
\hline Katherine & Sally & Jo & Penelope \\
3 & 2 & 4 & 2 \\
2 & 2 & 3 & 4 \\
1 & 2 & 3 & 3 \\
2 & 2 & 3 & 4 \\
3 & 2 & 4 & 4 \\
1 & 2 & 0 & 2
\end{tabular}




\begin{tabular}{lcccc}
\hline & \multicolumn{5}{c}{ Participants' Pseudonyms } \\
\cline { 2 - 6 } Fear of Compassion & Katherine & Sally & Jo & Penelope \\
\hline $\begin{array}{l}\text { 7. People need to help themselves rather than } \\
\text { waiting for others to help them }\end{array}$ & 3 & 3 & 4 & 4 \\
$\begin{array}{l}\text { 8. I fear that if I am compassionate, some people } \\
\text { will become too dependent upon me }\end{array}$ & 3 & 2 & 2 & 3 \\
$\begin{array}{l}\text { 9. Being too compassionate makes people soft and } \\
\text { easy to take advantage of }\end{array}$ & 3 & 2 & 3 & 3 \\
$\begin{array}{l}\text { 10. For some people, I think discipline and } \\
\text { proper punishments are more helpful than being } \\
\text { compassionate to them }\end{array}$ & 3 & 2 & 4 & 3 \\
\hline
\end{tabular}

\section{Appendix B}

Ways of Responding to the Expression of Compassion from Others

\begin{tabular}{lcccc}
\hline \multirow{2}{*}{$\begin{array}{l}\text { Ways of Responding to the Expression of } \\
\text { Compassion from Others }\end{array}$} & \multicolumn{5}{c}{ Participants' Pseudonyms } \\
\cline { 2 - 5 } $\begin{array}{l}\text { 1. Wanting others to be kind to oneself is a } \\
\text { weakness }\end{array}$ & 1 & 0 & 0 & 0 \\
$\begin{array}{l}\text { 2. I fear that when I need people to be kind and } \\
\text { understand they won't be }\end{array}$ & 1 & 2 & 2 & 1 \\
$\begin{array}{l}\text { 3. I'm fearful of becoming dependent on the care } \\
\text { from others because they might not always be } \\
\text { available or willing to give it }\end{array}$ & 1 & 2 & 0 & 4 \\
$\begin{array}{l}\text { 4. I often wonder whether displays of warmth and } \\
\text { kindness from others are genuine }\end{array}$ & 2 & 2 & 2 & 1 \\
$\begin{array}{l}\text { 5. Feelings of kindness from others are somehow } \\
\text { frightening }\end{array}$ & 1 & 0 & 3 & 1 \\
$\begin{array}{l}\text { 6. When people are kind and compassionate } \\
\text { towards me I feel anxious or embarrassed }\end{array}$ & 2 & 0 & 0 & 4 \\
\hline
\end{tabular}

Ways of Responding to the Expression of

Compassion from Others

7. If people are friendly and kind I worry they will

find out something bad about me that will change their mind

8. I worry that people are kind and compassionate if they want something from me

9. When people are kind and compassionate towards me I feel empty and sad

10. If people are kind I feel they are getting too close

11. Even though other people are kind to me, 1 have rarely felt warmth from my relationships with others

12. I try to keep my distance from others even if I know they are kind

13. If I think someone is being kind and caring towards me, I put up a barrier

\section{Appendix C}

Expressing Kindness and Compassion Towards Yourself

\begin{tabular}{|c|c|c|c|c|}
\hline \multicolumn{5}{|c|}{$\begin{array}{c}\text { Appendix C } \\
\text { Expressing Kindness and Compassion Towards Yourself }\end{array}$} \\
\hline \multirow{2}{*}{$\begin{array}{l}\text { Expressing Kindness and Compassion Towards } \\
\text { Yourself }\end{array}$} & \multicolumn{4}{|c|}{ Participants' Pseudonyms } \\
\hline & Katherine & Sally & Jo & Penelope \\
\hline $\begin{array}{l}\text { 1. I feel that I don't deserve to be kind and } \\
\text { forgiving to myself }\end{array}$ & 0 & 0 & 0 & 0 \\
\hline $\begin{array}{l}\text { 2. If I really think about being kind and gentle } \\
\text { with myself it makes me sad }\end{array}$ & 0 & 0 & 0 & 0 \\
\hline $\begin{array}{l}\text { 3. Getting on in life is about being tough rather } \\
\text { than compassionate }\end{array}$ & 1 & 2 & 2 & 3 \\
\hline
\end{tabular}

Participants' Pseudonyms

Katherine Sally Jo Penelope

$\begin{array}{llll}2 & 0 & 0 & 0\end{array}$

3 
Expressing Kindness and Compassion Towards Yourself

4. I would rather not know what being kind and compassionate to myself feels like

5. When I try and feel kind and warm to myself I just feel kind of empty

6. I fear that if I start to feel compassion and warmth for myself, I will feel overcome with a sense of loss/grief

7. I fear that if I become kinder and less selfcritical to myself then my standards will drop

8. I fear that if I am more self- compassionate I will become a weak person

9. I have never felt compassion for myself, so I would not know where to begin to develop these feelings

10. I worry that if I start to develop compassion for myself I will become dependent on it

11. I fear that if I become too compassionate to myself I will lose my self-criticism and my flaws will show

12. I fear that if I develop compassion for myself, I will become someone I do not want to be

13. I fear that if I become too compassionate to myself others will reject me

14. I find it easier to be critical towards myself rather than compassionate

15. I fear that if I am too compassionate towards myself, bad things will happen
Participants' Pseudonyms

Katherine Sally Jo Penelope

0

0

0

$0 \quad 0$

0

$0 \quad 0$

0

$0 \quad 0 \quad 0$

$0 \quad 3$

1

1

Appendix D

Katherine's Meditation During COVID-19

It was in February when I became aware that masks, alcohol, and sanitary wipes have started running out on the shelves of every store. Surely, the stores would re-stock these essentials, or so I thought. I had a few lucky tries when I went down early to the nearby drugstore and I was able to buy a box of masks enough to last for a month.

A few days before I was to run out of my own supply, I again tried my luck and unfortunately, I didn't get them. I was getting worried, but not losing hope. I talked to my family about my situation, and they tried to help me by sending masks. I felt relieved and thankful that I had the means to tell my family about my situation.

In the days that followed, the atmosphere drastically changed. From our normal end of the year preparations, graduation rehearsal, wrap-up classes we had an abrupt end to what would have been another busy school year. When the government announced their request to close the schools to stop the spread of the virus, the first thing that came to my mind was "how about me/us - the outsiders of the school? I was worried for a time because without reporting to school, my salary would be affected. After telling my family about my situation, I let it rest and told myself, this is beyond my control. (Acceptance helped her less anxious about the situation)

During these uncertain times, I tried to find ways to distract myself from worries (But is quite a challenge.) and care for myself. Since February, I had an urge to look for some meditation guides, to help me ease my mind especially before going to sleep. The breathing exercise at the start of the podcast feels as if it unburdens my heavy shoulders and relaxes my stiff body. It clears my thoughts and prepares me for my prayer time. It has helped me focus on my praying and has helped me have a good sleep.

It's been more than a month since I started listening to the meditation podcast. I haven't noticed any major changes yet but is starting to be a regular in my nightly routine. I look forward to the soft breathing exercise as a way to put my mind at ease before I sleep.

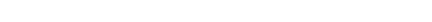

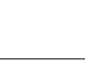

0

